\title{
KETERATURAN SOSIAL DALAM BENTUK GOTONG ROYONG MENGELOLA KEBERSIHAN LINGKUNGAN DI KELURAHAN MENTENG KECAMATAN JEKAN RAYA KOTA PALANGKA RAYA
}

\author{
Fauzi Rahman \\ Fakultas IImu Sosial dan IImu Politik Universitas PGRI Palangka Raya \\ (email: jibranfauzi05@gmail.com) \\ Wijoko Lestariono \\ Fakultas IImu Sosial dan IImu Politik Universitas Palangka Raya \\ (email: wijokolestariono@gmail.com)
}

\begin{abstract}
Abstrak
Adapun tujuan dari penelitian ini adalah Ingin mengetahui keteraturan sosial dalam bentuk gotong royong mengelola kebersihan lingkungan di Kelurahan Menteng, Kecamatan Jekan Raya Kota Palangka Raya, Ingin mengetahui faktor-faktor yang menjadi pendorong dan penghambat keteraturan sosial dalam bentuk gotong royong mengelola kebersihan lingkungan di Kelurahan Menteng, Kecamatan Jekan Raya Kota Palangka Raya.

Penelitian ini menggunakan metode deskriptif adalah penelitian yang diarahkan untuk memberikan gejala-gejala, fakta-fakta, atau kejadian - kejadian secara sistematis dan akurat, mengenai sifat-sifat populasi atau daerah tertentu. Dalam penelitian deskriptif cenderung tidak perlu mencari atau menerangkan saling berhubungan,Sesuai dengan masalah yang penulis ajukan, maka penulis menggunakan metode penelitian kualitatif yaitu suatu proses penelitian dan pemahaman yang berdasarkan pada metodologi yang menyelidiki suatu fenomena sosial dan masalah manusia. Pada pendekatan ini, peneliti membuat suatu gambaran kompleks, meneliti kata-kata, laporan terperinci dari pandangan informan, dan melakukan studi pada situasi alami. Adapun metode yang digunakan dalam penelitian ini adalah metode deskriptif.

Hasil kesimpulan penelitian ini adalah Keteraturan sosial masyarakat dalam kegiatan gotong royong mengelola kebersihan di Kelurahan Menteng dapat dilihat dari beberapa karakteristik yaitu Tertib Sosial, Sosial Order, Keajegan dan Pola. Tertib sosial masyarakat dalam mengelola kebersihan dilingkungan kelurahan menteng berpedoman kepada norma tertulis dan berupa himbauan dari ketua rukun tetangga. Pengetahuan tentang kebersihan telah diinternalisasi sejak masih sekolah namun dalam praktek sehari-hari mengalami kendala berupa kurangnya kesadaran kolektif warga diakibatkan sosial control yang lemah dan sangsi atas tindakan tidak berlaku efektif. Faktor penghambat adalah hubungan sekunder warga yang hanya memenuhi keinginan dari ketua warga sebagai tokoh masyarakat yang menggambarkan kehadiran semu warga dan toleransi yang rendah karena individualisme tinggi warga serta
\end{abstract}

\section{Jurnal Sociopolitico}


kurangnya kesadaran koletif warga akibat perubahan sosial masyarakat kota. Faktor pendorong berupa kerjasama terlihat pada masyarakat yang tinggal secara permanen dan peran tokoh Ketua RT dalam menyeimbangkan, mempersatukan, kepentingan warga masyarakat.

\section{Kata Kunci: Keteraturan Sosial Mengelola Kebersihan Lingkungan}

\section{Pendahuluan}

Kesehatan merupakan salah satu hal terpenting untuk mendukung kualitas kehidupan manusia selama hidupnya. Kesehatan dapat dicapai dengan berbagai macam hal, salah satunya adalah dengan menerapkan perilaku hidup bersih dan sehat (PHBS). Manusia dapat hidup dengan sehat apabila lingkungan di sekitarnya pun sehat. Salah satu permasalahan yang dihadapi oleh masyarakat Indonesia adalah perilaku buang air besar sembarangan yang masih banyak dilakukan oleh masyarakat.

Menurut Menteri Perencanaan Pembangunan Nasional / Kepala Bappenas Bambang Brodjonegoro mengatakan Indonesia menempati peringkat kedua di dunia sebagai negara dengan sanitasi terburuk. Sebab, sebagian besar masyarakat melakukan $\mathrm{BAB}$ sembarangan di berbagai tempat

Berbagai upaya telah dilakukan oleh Pemerintah untuk meningkatkan kapasitas dan kualitas pengelolaan sanitasi di daerah, terutama untuk menghindari dampak dari kondisi buruknya sanitasi di Indonesia. Beberapa upaya yang telah dilakukan pemerintah termasuk: (i) Konferensi Sanitasi Nasional, yang menghasilkan kesepakatan mengenai langkah-langkah penting bagi pembangunan sanitasi ke depan yang juga sejalan dengan pencapaian sasaran MDGs;

(ii) pertemuan International Year of
Sanitation (IYOS), yang menghasilkan komitmen pemerintah dalam pengarusutamaan pembangunan sanitasi; dan (iii) Konvensi Strategi Sanitasi Perkotaan.

Pada event ini telah pula diidentifikasi permasalahan dan sasaran pembangunan sanitasi ke depan serta menyepakati pendekatan Strategi Sanitasi Kota (SSK) sebagai dasar pembangunan sanitasi di daerah. Selain itu, Untuk menghadapi tantangan yang dihadapi dalam pengelolaan air limbah, persampahan dan drainase permukiman diperlukan Kebijakan Pemerintah sebagai terobosan, yaitu dengan melibatkan partisipasi masyarakat, lembaga masyarakat dan pihak swasta. Untuk mendukung kebijakan, perlu adanya upaya untuk meningkatkan pemahaman dan pengetahuan serta persamaan persepsi tentang mekanisme kerjasama pemerintahswasta.

\begin{tabular}{llr}
\multicolumn{2}{c}{ Dengan demikian } & semua \\
stakeholder yang terkait & dengan \\
penanganan & prasarana dan & sarana
\end{tabular}
penyehatan lingkungan permukiman, baik pihak pemerintah maupun pihak swasta yang beminat dapat melihat adanya peluang kerjasama ini sebagai peluang investasi. Indonesia sangat tertinggal dalam akses sanitasi sehingga diperlukan percepatan peningkatan akses maupun kualitas sanitasi 
di seluruh pelosok tanah air. Dengan terpenuhinya kebutuhan sanitasi masyarakat dengan baik, maka akan menentukan kualitas hidup masyarakat tersebut, karena sanitasi merupakan salah satu hajat hidup dasar dari seluruh masyarakat.

Tantangan yang dihadapi dalam pengelolaan air limbah, persampahan dan drainase permukiman adalah bagaimana melakukan penanganan secara lebih baik, sehingga diperoleh: (1) Peningkatan kualitas dan cakupan pelayanan air limbah, persampahan, dan drainase yang dapat mengiringi peningkatan pertumbuhan penduduk yang pesat terutama di daerah perkotaan; (2) Penurunan angka sakit dan kematian yang disebabkan oleh waterborne diseases terutama pada bayi dan anak-anak; (3) Pemenuhan sasaran Millenium Development Goals (MDGs) oleh pemerintah, yaitu : untuk dapat melayani separuh dari populasi penduduk yang belum mendapatkan akses sanitasi (air limbah dan sampah) sampai tahun 2015 secara bertahap; (4) Terciptanya lingkungan hidup yang bersih, sehat, nyaman, dan layak huni.

Program-program tersebut berjalan
dengan berbagai cara dalam upaya
mencapai keberhasilan. Masing-masing
program memiliki indikator keberhasilan.
Dalam mencapai keberhasilan program,
terdapat faktor-faktor pendukung yang
membantu tercapainya indikator-indikator
keberhasilan program. Program yang
berdasarkan basis masyarakat maka akan
mengutamakan peranan masyarakat dalam
pelaksanaan program. Setiap indikator,
faktor, dan peranan masyarakat akan

Program-program tersebut berjalan dengan berbagai cara dalam upaya mencapai keberhasilan. Masing-masing program memiliki indikator keberhasilan Dalam mencapai keberhasilan program, terdapat faktor-faktor pendukung yang membantu tercapainya indikator-indikator keberhasilan program. Program yang berdasarkan basis masyarakat maka akan faktor, dan peranan masyarakat akan menentukan bagaimanakah keberhasilan program yang dicapai.

Masyarakat sebagai salah satu instrumen dari pembangunan dirasa perlu memberikan partisipasinya secara maksimal dalam berbagai aspek pembangunan baik aspek perencanaan maupun sampai aspek pengawasan pembangunan. Pembangunan yang baik harusnya juga mencakup Partisipasi masyarakat dalam kelancaran dan keberhasilan dari sesuatu program pembangunan. Sebagaimana diungkapkan Siswanto (2012:32) bahwa Kunci keberhasilan pengelolaan pembangunan tergantung pada tingginya motivasi dan keswadayaan sebagai buah dari adanya peluang yang lebih terbuka dalam berpartisipasi dan dibebaskannya masyarakat memutuskan pilihan kegiatan sesuai kebutuhannya secara demokratis.

Partisipasi masyarakat di Kelurahan Menteng dalam mengelola sanitasi dan lingkungan masih tergolong rendah. Fenomena yang terjadi adalah kondisi pemukiman penduduk beragam, sesuai dengan strata ekonomi masyarakat. Posisi rata-rata pemukiman yang berada pada daerah rawa, mengharuskan pemerintah membuat saluran drainase (pengaringan, parit) sebagai resapan air agar pemukiman penduduk tidak tergenang air bila musim penghujan tiba. Apabila tergenang air maka berpotensi terhadap endemic penyakit demam berdarah, Gejala ini disampaikan oleh Kepala Dinas Komunikasi dan Informasi Kota Palangka Raya melalui tribunnews.com:

"Banyak sekali keluhan soal DBD yang kian gencar menyerang warga Palangkaraya dalam beberapa beberapa minggu ini, mereka melaporkannya melalui pesan elektronik di website yang kami 
buka dan mengharapkan agar dilakukan pogging,"

Bahkan laporan dari Kepala Rumah Sakit (RS) Doris Sylvanus Palangka Raya, Yayu Indriarti, menyebut kasus demam berdarah Dengue (DBD) yang terjadi di Kota Palangka Raya, Kalimantan Tengah, dalam Bulan November 2018 mencapai ratusan orang dan Data Rumah Sakit Daerah Doris Sylvanus Palangka Raya tercatat jumlah penderita mencapai 162 pasien selama Bulan November 2018 yang meninggal ada empat orang.

Hal lainnya ada gejala lingkungan daerah kelurahan menteng , kurang memenuhi pola hidup bersih dan sehat, hal ini terlihat banyak saluran air yang mampet, sampah plastik yang hampir ada pada setiap saluran air, dan ada beberapa ruas jalan yang tidak ada draninasenya. Sehingga rawan terhadap genangan air, pemandangan yang tidak nyaman, mengganggu keindahan kota serta berpotensi membahayakan bagi masyarakat sekitar.

Dalam suatu masyarakat bagaimanapun sederhananya, selalu ada suatu mekanisme untuk bereaksi terhadap suatu stimulasi. Mekanisme ini disebut mekanisme pemecahan atau proses pemecahan masalah. Mengembangkan dan membina partisipasi masyarakat sebenarnya tidak lain merupakan upaya mengembangkan mekanisme atau proses pemecahan masalah tersebut agar terdapat kesesuaian antara keinginan pemrakarsa dengan keinginan masyarakat

Sementara tugas menjaga kebersihan lingkungan tidak saja kewajiban pemerintah, namun juga harus melibatkan partisipasi masyarakat yang digerakkan oleh perangkat pemerintah maupun tokoh masyarakat (RT/RW) yang ditunjuk. Namun dewasa ini hal-hal demikian makin jarang di jumpai. Terkait dengan hal ini kegiatan gotong royong, cenderung berkurang, menurut pengamatan terdahulu hasil wawancara dengan beberapa warga, dahulu banyak kegiatan yang dilakukan dengan cara bergotong royong, misalnya masyarakat kompak dan aktif ikut berpartisipasi mendistribusikan ide serta pemikiran pada setiap musyawarah yang rutin dilaksanakan setahun sekali dalam kelurahan guna dalam peningkatan pembangunan dalam kelurahan.

Bergotong royong merupakan salahsatu bentuk keteraturan sosial berbentuk kerjasama, fungsi serta manfaatnya juga dirasakan oleh masyarakat dengan bergotong royong terlebih dalam menyelesaikan pekerjaan yang membutuhkan tenaga lebih banyak. Namun terkait dengan bergotong royong dewasa ini sudah jarang ditemui, hal ini disebabkan banyak faktor yang melatarbelakanginya misalnya lunturnya nilanilai sosial masyarakat dan kesadaran masyarakat mengenai pentingnya pola hidup bersih dan sehat perlu di pertanyakan kembali.

\section{Metode Penelitian}

Jenis penelitian yang digunakan dalam penelitian ini adalah kualitatif dengan strategi deskriptif. Penelitian ini menghendaki suatu informasi dalam bentuk deskripsi dan lebih menghendaki makna yang berada dibalik deskripsi data tersebut. Menurut Zuriah (2006:47) penelitian dengan menggunakan metode deskriptif adalah penelitian yang diarahkan untuk memberikan gejala-gejala, fakta-fakta, atau kejadian - kejadian secara sistematis dan akurat, mengenai sifat-sifat populasi atau daerah tertentu. Dalam penelitian deskriptif cenderung tidak perlu mencari atau menerangkan saling berhubungan.

\section{Jurnal Sociopolitico}


Sesuai dengan masalah yang penulis ajukan, maka penulis menggunakan metode penelitian kualitatif yaitu suatu proses penelitian dan pemahaman yang berdasarkan pada metodologi yang menyelidiki suatu fenomena sosial dan masalah manusia. Pada pendekatan ini, peneliti membuat suatu gambaran kompleks, meneliti kata-kata, laporan terperinci dari pandangan informan, dan melakukan studi pada situasi alami. Adapun metode yang digunakan dalam penelitian ini adalah metode deskriptif.

Penelitian kualitatif adalah penelitian deskriptif yang bertujuan untuk membantu menjelaskan karakteristik objek dan subjek penelitian" (Arikunto 1998, h. 88)

$$
\text { Maka dapat disimpulkan }
$$

bahwa metode penelitian kualitatif adalah metode penelitian yang nantinya data yang ditemukan, diolah sehingga menghasilkan data deskriptif berupa katakata tertulis atau lisan dari orang-orang dan perilaku yang diamati pada obyek penelitian dan subyek penelitian.

\section{Hasil dan Pembahasan}

\section{Keteraturan Sosial Dalam Bentuk Gotong Royong Mengelola Kebersihan Lingkungan Di Kelurahan Menteng, Kecamatan Jekan Raya Kota Palangka Raya}

Setiap masyarakat pasti memiliki nilai dan norma yang dihormati dan dijunjung tinggi oleh anggota masyarakat sebagai pedoman bagi perilaku dalam kehidupan. Proses kehidupan anggota masyarakat yang selalu menggunakan nilai dan norma sebagai pedoman perilaku itu akan menciptakan suatu kehidupan masyarakat yang teratur dan tertib. Sebagaimana menurut Al Hakim (2015:51) keteraturan sosial masyarakat dapat dilihat dari tiga syarat yaitu norma- norma sosial, nilai-nilai sosial dan lembaga sosial,.

Dilain pihak keteraturan sosial terbentuk karena adanya proses sosial yang dinamakan komformitas, yaitu bentuk interaksi sosial yang didalamnya seseorang berperilaku terhadap yang lain sesuai dengan harapan kelompok. Menurut penganut teori fungsional structural, mesikipun didalam masyarakat terdapat unsur-unsur sosial yang berbeda, tetapi unsur-unsur tersebut cenderung saling menyesuaikan sehingga membentuk suatu keseimbangan dalam kehidupan sosial. Wujud nyata keseimbangan ini adalah keteraturan sosial yaitu kondisi dimana cara berpikir, berperasaan dan bertindak serta interaksi sosial antara para warga masyarakat selaras dengan nilai-nilai dan normanorma sosial yang berlaku didalam masyarakat itu sendiri.

Selanjutnya keteraturan sosial akan tercipta dalam masyarakat apabila :

a. Terdapat system nilai dan norma sosial yang jelas. Jika nilai dan norma dalam masyarakat tidak jelas akan menimbulkan keadaan yang dinamakan anomie (kekacauan norma).

b. Individu dan kelompok dalam masyarakat mengetahui dan memahami nilai-nilai dan normanorma yang berlaku

c. Individu atau kelompok menyesuaikan tindakan-tindakannya dengan nilai-nailai dan norma-norma yang berlaku.

d. Berfungsinya system pengendalian sosial (social control).

Dengan memperhatikan realitas empiric (Al Hakim, 2015) maka salah satu 
bentuk keteraturan sosial yang teridentifikasi adalah kerjasama-kerjasama (cooperation) merupakan bentuk interaksi sosial yang pokok. Kerjasama dapat menggambarkan sebagian besar untuk interaksi sosial. Segala macam bentuk interaksi tersebut dapat dikembalikan pada kerjasama. Kerjasama dimaksudkan sebagai suatu usaha bersama antarpribadi atau antar kelompok manusia untuk mencaai suatu atau beberapa tujuan bersama. "di kalangan masyarakat Indonesia dikenal bentuk kerja sama tradisional, yaitu gotong royonng. Di dalam sistem pendidikan Indonesia yang tradisional umpamanya, sejak kecil telah ditanamkan dalam jiwa anak suatu pola perilaku agar hidup rukun,, terutama dengan keluarga dan lebih luas lagi dengan orang lain di dalam masyarakat. Hal ini disebabkan adanya suatu pandangan hidup bahwa seseorang tidak mungkin hidup sendiri tanpa kerja sama dengan orang lain. Pandangan hidup demikian diangkat menjadi pandangan hidup masyarakat sehingga gotong royong seringkali diterapkan untuk menyelenggarakan suatu kepentingan.

Dari kajian diatas maka kajian keteraturan sosial mengenai kerjasama gotong royong dalam pengelolaan kebersihan lingkungan dilingkungan Kelurahan Menteng sebagai berikut:

a. Tertib Sosial Mengenai Kebersihan Lingkungan Di Kelurahan Menteng

Pemahaman dan pengetahuan warga masyarakat kelurahan umumnya terhadap hidup bersih dan sehat cukup memadai, hal mana dari segi pendidikan dan kehidupan masyarakat tergolong menengah keatas. Warga masyarakat ratarata berpendidikan tinggi tentunya sangat mengerti tentang arti bersih dan sehat. Selain itu adanya norma hukum yang mengatur kehidupan masyarakat hidup dalam suasana bersih dan sehat terdapat dalam peraturan daerah Kota Palangka Raya nomor 3 tahun 2006 tentang pengelolaan kebersihan lingkungan dan pertamanan, di mana setiap warga masarakat pelaku mempunyai hak dan kewajiban dalam menciptakan kebersihan lingkungan yang bersih dan sehat.

Menguatkan pendapat diatas bahwa kenyataannya setiap warga dari tingkat pendidikan usia dini sampai dewasa telah mendapat sosialisasi dan internalisasi nilai-nilai hidup bersih, Anak diajar membuang sampah pada tempatnya atau tempat sampah yang sudah disediakan, bersama-sama membersihkan kelas, dan membersihkan halaman sekolah, jadi proses tersebut telah berlangsung sejak mereka mulai bersosialisasi dengan lingkungan sekitarnya.

Dari hasil wawancara seluruh informan menyatakan mengetahui nilainilai kebersihan lingkungan yang berlaku dimasyarakat, terlebih lagi bagi mereka yang mengenyam pendidikan sampai tingkat atas, tentunya sangat memahami sekali tentang arti kebersihan, dan dapat membedakan keadaan bersih dan kotor dengan demikian telah tercipta konstruksi sosial mengenai kebersihan.

Sebagian masyarakat kelurahan Menteng beranggapan bahwa dengan hidup bersih akan menciptakan keindahan dan keselarasan dalam hidup. Namun walaupun proses internalisasi mengenai kebersihan dilakukan, pengelolaan kebersihan di lingkungan kelurahan Menteng masih jauh dari harapan.

Beberapa pandangan dari informan menyatakan bahwa sangsi 
tidak berlaku efektif menandakan social control dari masyarakat masih lemah. Masih banyak warga masyarakat yang membuang sampah sembarangan, membuang sampah ke TPS tidak dalam waktu-waktu yang telah ditentukan, terlebih lagi kebersihan lingkungan secara lebih luas.

Adanya peran dan tanggung jawab warga mengenai kebersihan lingkungan dibebankan kepada Ketua RT/RW, dengan kata lain bahwa peran $\mathrm{RT} / \mathrm{Rw}$ sangat besar dalam menciptakan suasana bersih, indah dan rapi, maka baik dan buruknya lingkungan tergantung kepekaan sosial dari pemangku jabatan Ketua RT. Mengenai pertanyaan apakah semua warga telah bertindak sesuai dengan fungsi dan perannya dalam menjaga kebersihan lingkungan? Pada kenyataannya tidak semua warga melaksanakan kewajiban tersebut, kepedulian terhadap lingkungan sangat kurang dan keikutsertaan warga bergotong royong membersihkan lingkungan belum menimbulkan solidaritas sosial antar warga, warga lebih mementingkan kehidupan pribadi daripada kepentingan orang banyak.

b. Tatanan Sosial (sosial order)

Dari hasil observasi dan wawancara dengan informan bahwa nilai -nilai yang diakui dan dipatuhi dalam menciptakan kebersihan lingkungan di Kelurahan Menteng adalah : pertama, gotong royong, dan kedua. Menghormati peran status simbol.

Kegiatan yang banyak menyerap orang banyak di lingkungan tempat tinggal adalah gotong royong, hal ini dilakukan sehubungan dengan pekerjaan yang mengharuskan memobilisasi sumber daya yang besar, begitu berat bila di kelola secara pribadi, hasil wawancara masih tergambar setiap warga berpartisipasi dalam acara peringatan hari kemerdekaan yang dilaksanakan setiap tahunnya, membuat dan mengaktifkan siskamling dan pembersihan lokasi acara hiburan rakyat, dalam suasana tersebut warga ikut ambil bagian dalam menyukseskan acara, bila dilihat dari kekuatan mengikat norma maka masih dalam taraf biasa (usage), sangsi moral dikenakan hanya berupa celaan dan pergunjingan orang banyak dan dari pribadi yang bersangkutan menimbulkan perasaan tidak enak.

Selanjutnya nilai yang kedua yang dianggap diakui dan dipatuhi adalah menghormati peran status symbol, dalam hal ini adalah peran Ketua RT. Penghormatan berupa kepatuhan terhadap peran Ketua RT yang cukup besar mengharuskan warga terlibat dalam kegiatan gotong royong, norma kepatuhan tersebut merupakan kekuatan yang memaksa dari pengaruh jabatan yang menjadi status symbol dimasyarakat, ketidakmampuan ketua RT memainkan peran berakibat memudarnya pengaruh dan kepatuhan terhadap norma menjadi berkurang.

c. Konsistensi perilaku masyarakat dalam menjaga kebersihan lingkungan di Kelurahan Menteng (keajegan)

Dilihat dari cara masyarakat kelurahan menteng berperilaku dalam mewujudkan kebersihan dilingkungannya maka dapat dilihat dari dua golongan, pertama adalah penduduk yang telah lama menetap dan kedua adalah warga pendatang. Bagi penduduk yang menetap menjaga kebersihan lingkungan dengan kerja bakti gotong royong merupakan sebuah keharusan moral yang harus ditanggung pribadi warga, sebaliknya bagi pendatang tidak ada sangsi moral yang

\section{Jurnal Sociopolitico}


mengikat hal ini didasarkan kepada temuan lapangan dimana ada banyak warga pendatang karena waktu berdomisili yang singkat dan dengan profesi sebagai mahasiswa mempengaruhi keikutsertaan dalam suasana gotong royong.

Sehubungan dengan keberadaan warga pendatang cukup beralasan bila membantu kegiatan gotong royong membersihkan lingkungan juga mempengaruhi sikap individu warga, menjadi individualis dalam tatanan sosial masyarakat, nilai-nilai gotong royong menjadi longgar, warga masyarakat menyerahkan kebersihan lingkungan pribadi dengan cara mengupah orang lain, sebaliknya mengabaikan keadaan kebersihan lingkungan sekitarnya seperti terungkap di kawasan pameran jalan Temanggung Tilung 16, sampah menumpuk ketika sudah habis acara pameran dan tidak dibersihkan sebagaimana mestinya. Pembersihan dilakukan dengan mengupah petugas pasukan kuning.

Selain itu pula ketidakpatuhan warga dalam membuang sampah di TPS tidak berpedoman kepada aturan yang sudah ditetapkan oleh peraturan daerah, banyak warga membuang sampah di TPS diluar jam 18.00 wib s/d 03.30, hal ini mengakibatkan menumpuknya sampah dan menimbulkan pemandangan yang kurang sedap dan menjalarnya berbagai penyakit menular.kondisi ini akan mengakibatkan kegagalan dalam menciptakan keteraturan sosial.

Dilain pihak sebagian besar warga melakukan pembuangan sampah dengan berlangganan kepada petugas swasta dan dikenakan biaya dengan upah yang beragam tergantung dengan jumlah pengambilan sampah, konsistensi terhadap hal ini cenderung mengakibatkan sampah rumah tangga dapat teratasi dengan baik dan tidak menyebabkan terganggunya kesehatan warga, maka keteraturan sosial mengalami keberhasilan.

d. Model interaksi warga dalam menjaga kebersihan lingkungan di Kelurahan Menteng (Pola).

Dari hasil penelitian yang dilakukan didapat temuan bahwa pra kondisi kegiatan menjaga kebersihan lingkungan di Kelurahan Menteng adalah dengan mengadakan musyawarah pada tingkat kelurahan dengan melibatkan para ketua RT/RW dan beberapa tokoh masyarakat, musyawarah ini dalam rangka sosialisasi kegiatan yang dilaksanakan, dalam hal ini adalah kegiatan kerjabakti membersihkan lingkungan disekitar wilayah masing-masing rukun tetangga. Pola interaksi melalui musyawarah dilakukan oleh pemerintah kelurahan Menteng menandakan bahwa pola hubungan antara pemerintah dan warganya dalam memecahkan masalah dilakukan dengan pertemuan atau musyawarah, dengan musyawarah semua persoalan dibicarakan secara terbuka sehingga secara factual hasil yang dilaksanakan dapat dipertanggungjawabkan secara normatif.

Selanjutnya pola hubungan interaksi warga masyarakat dalam keteraturan sosial dikelurahan menteng melalui kegiatan gotong royong dalam memeriahkan hari kemerdekaan pada setiap menjelang puncak perayaan tanggal tujuh belasan, komunikasi, hubungan emosional warga tercipta secara otomatis, suasana akrab dirasakan seluruh warga. Kegiatan warga dapat berlangsung sukses karena keterlibatan seluruh elemen masyarakat dari semua strata sosial masyarakat. Hasil penelitian menunjukkan bahwa warga dengan sukarela menyiapkan waktu untuk membersihkan halaman sekitarnya, bersama-sama membersihkan

\section{Jurnal Sociopolitico}


gapura, mengaktifkan siskamling, mengecat pagar dan membersihkan lokasi acara hiburan masyarakat sampai selesai nya acara. Motivasi masyarakat tercipta karena ada semangat kebersamaan menyukseskan acara tujuh belasan, sebagaimana John Field (2010) dalam bukunya Modal sosial menyatakan bahwa dengan membangun hubungan dengan sesama, dan menjaganya agar terus berlangsung sepanjang waktu, orang mampu bekerja bersama-sama untuk mencapai berbagai hal yang tidak dapat mereka lakukan sendirian, atau yang dapat mereka capai tapi dengan susah payah

2. Faktor- Faktor Pendorong Dan Penghambat Keteraturan Sosial Dalam Bentuk Gotong Royong Mengelola Kebersihan Lingkungan di Kelurahan Menteng, Kecamatan Jekan Raya Kota Palangka Raya

Masyarakat yang teratur dapat dicapai apabila setiap individu melaksanakan kewajiban dan menerima haknya dari orang lain. Salah satu kewajiban yang harus dilakukan individu agar terwujud keteraturan sosial adalah menaati norma dan nilai-nilai yang terdapat dalam masyarakat tersebut. Keteraturan sosial tidak terlepas dari unsur-unsur, nilainilai, kebudayaan, dan sikap yang menjadikan dasar dalam menentukan sesuatu yang penting dan benar, maka dalam kasus pengelolaan kebersihan lingkungan di Kelurahan Menteng, terdapat factor-faktor yang menentukan keberhasilan mewujudkan keteraturan sosial dimaksud diantaranya adalah :

Faktor penghambat berupa:

a. Hubungan sekunder

Berdasarkan temuan penelitian, warga masyarakat melakukan kegiatan gotong royong karena ada kepentingan yang mendesak warga harus berpartisipasi aktif dalam menghadirkan dirinya ketengah-tengah masyarakat. Beberapa informan merasa tidak enak bila tidak mengikuti kegiatan masyarakat berhubung ada himbauan dari ketua rukun tetangga setempat, sebisa mungkin menyediakan waktu dalam rangka memenuhi undangan untuk kerja bakti dalam rangka menghias lingkungan guna memeriahkan acara tujuh belas agustusan.

Menurut Suparlan Al Hakim (2015) dalam bukunya pengantar Studi Masyarakat Indonesia , menandakan masyarakat kelurahan Menteng masuk dalam kategori masyarakat kota yang membatasi hubungan sebatas fungsional belaka, artinya setiap hubungan yang dilakukan karena adanya kepentingan, pengenalan dengan orang seba terbatas pada bidang hidup tertentu saja, dalam kasus ini bahwa kecenderungan masyarakat membantu kegiatan karena tidak ingin dikucilkan dari pergaulan dan juga menghindari pergunjingan dari masyarakat, warga yang menggantungkan kepentingannya kepada Ketua Rukun tetangga akan merasa bersalah bila tidak mengikuti kegiatan dilingkungan. Maka dari itu kehadiran seseorang dalam kegiatan walaupun hanya sebentar cukup menggambarkan kepedulian mereka terhadap lingkungan.

b. Rendahnya Toleransi Masyarakat terhadap pengelolaan lingkungan

Warga masyarakat di kelurahan Menteng ada dua golongan yaitu Asli atau yang menetap secara permanen dan pendatang karena sewaktu-waktu pindah berhubung berperan sebagai mahasiswa dan atau perantau, dari temuan tersebut kenyataannya warga pendatang kurang dapat menjalin komunikasi yang efektif dengan warga sekitar yang hidup menetap permanen, menurut Al Hakim (2015) dalam 
karakteristik masyarakat kota, orang hampir tidak memperdulikan tingkah laku pribadi sesamanya, walaupun ada social control bila ada perilaku yang mengganggu ketertiban umum akan berhadapan dengan masyarakat banyak atau penegak hukum, namun apabila tidak maka tindakan dapat ditoleransi. Orang-orang kota secara fisik berdekatan namun secara sosial berjauhan.

Ketika ada kegiatan masal melibatkan orang banyak, peserta yang antusias berasal dari warga yang menetap secara permanen, dan sikap yang ditunjukkan warga pendatang terkesan biasa dan lebih cenderung pasif. Gejala ini menandai bahwa adanya toleransi yang rendah dari warga pendatang, sebagaimana juga Paul Horton dan Chester L Hunt menyatakan bahwa lunturnya system hukum dan ketertiban tradisional manakala para pendatang dari luar membawa perubahan sosial dan berbagai masalah baru akan pindah.

c. Kurangnya kesadaran kolektif

Temuan penelitian mengenai tata pengelolaan kebersihan yang melibatkan warga masyakat tergambar dari kebiasaan warga memenuhi kebutuhan sendiri dalam menangani kebersihan lingkungan pribadi tanpa melibatkan bantuan tetangga sekitar, menyiratkan individualisasi yang tinggi, orang bisa memutuskan apa saja secara pribadi, lahan kota yang relative permanen dan arus urbanisasi yang semakin maju, akan membekukan pikiran orang untuk berpikir mengenai kehidupan orang lain sebagaimana Al Hakim (2015) menyatakan individualisasi condong semakin tinggi. Dengan demikian lebih terasa bila ada kegiatan yang melibatkan orang banyak maka kaum pendatang cenderung menghindari kegiatan, walaupun demikian ada juga warga pendatang yang membantu namun tidak signifikan dengan jumlah pendatang yang diharapkan partisipasinya. Faktor pendorong berupa

a. Kerjasama

Hasil penelitian menemukan jalinan kerjasama antar warga masyarakat sebagian telah tercipta dengan adanya dorongan untuk tetap eksis dari warga yang menetap permanen/lama, dimana keberadaannya semakin kalah jauh dengan arus urbanisasi, mobilitas yang sangat tinggi maka mendorong terciptanya masyarakat yang pluralistic dan multi kultural dalam kehidupan kota (Al hakim, 2015), maka pemaknaan gotong royong mengelola kebersihan beragam pula. Warga lokal lebih memaknai gotong royong sebagai bagian dari kehidupan bersama menyelesaikan masalah yang tidak bisa dipikul secara sendiri-sendiri, namun warga pendatang memaknai nya sebagai proses menyesuaikan diri dengan warga sekitar, bila sesuai dilakukan dan bila tidak dihindari.

\section{b. Peran Tokoh}

Sebagai ciri solidaritas sosial organic pada masyarakat kota dicirikan adanya ketergantungan satu sama lain semakin tinggi akibat bertambahnya spesialisasi pembagian pekerjaan dan peran. Sehingga orang akan membutuhkan orang lainnya guna mencukupi kehidupannya (Al Hakim, 2015). Dalam hubungannya dengan penelitian maka hubungan warga satu dengan sebagian warga akan sangat tergantung dengan peran rukun tetangga yang dianggap sentral dapat mengintegrasikan kepentingan masyarakat yang berbeda-beda dalam penelitian ini adalah mewujudkan keteratuan sosial melalui kerjasama gotong royong. Ajakan ataupun himbauan akan lebih didengar ketimbang nanti sulitnya berurusan ketika ada permasalahan yang melibatkkan peran ketua rukun tetangga. Dengan adanya 
kesadaran tersebut dapat mendukung kesuksesan mewujudkan keteraturan sosial, dimana setiap warga akan memahami hak dan kewajiban sebagai warga, dan bagi Ferdinant Tonnies menguatkan masyarakat gesellchaft yang mengutamakan hubungan sosial didasarkan pada spesialisasi tertentu, lebih rasional dan terencana dan secara sosial menguntungkan dirinya. Sebagaimana juga penelitian Alias dkk (2013) dengan judul Kontrol Sosial Tokoh Masyarakat (Ustad) Dalam Mengatasi Penyimpangan Perilaku Remaja Di Desa Limbung Kecamatan Sungai Raya Kabupaten Kubu Raya yang menyatakan Kontrol sosial ustazd yang telah dilakukan dalam mengatasi perilaku menyimpangan sosial remaja dengan pendekatan preventif.

Sehubungan dengan penelitian yang dilakukan bahwa maka peran tokoh Ketua RT dalam Pengendalian Sosial dimana individu dianjurkan, dibujuk, ataupun dipaksa untuk menyesuaikan diri pada kebiasaan dan nilai hidup suatu kelompok masyarakat. Dengan status symbol yang diberikan masyarakat secara bersama menyimpan harapan segala kepentingan yang menyangkut kepentingan orang banyak dapat di kendalikan dan dikoordinir oleh ketua RT.

\section{Kesimpulan}

Keteraturan sosial masyarakat dalam kegiatan gotong-royong mengelola kebersihan di Kelurahan Menteng dapat dilihat dari beberapa karakteristik yaitu Tertib Sosial, Sosial Order, Keajegan dan Pola.

1. Tertib sosial masyarakat dalam mengelola kebersihan dilingkungan kelurahan menteng berpedoman kepada norma tertulis dan berupa himbauan dari ketua rukun tetangga. Pengetahuan tentang kebersihan telah diinternalisasi sejak masih sekolah namun dalam praktek sehari-hari mengalami kendala berupa kurangnya kesadaran kolektif warga diakibatkan sosial control yang lemah dan sangsi atas tindakan tidak berlaku efektif.

2. Pada tatanan Sosial Order, nilai -nilai yang masih ada di masyarakat adalah gotong royong dan menghormati tokoh, maka masyarakat terbagi dua golongan yaitu warga yang menetap dan warga pendatang yang tidak menetap, memiliki perilaku berbeda dalam menyikapi kebersihan lingkungan, sebaliknya kekuatan norma dalam taraf biasa (usage) bila tidak ikutserta dalam gotong royong berupa pergunjingan dan perasaan yang tidak enak.

3. Pada tahapan keajegan atau konsistensi perilaku masyarakat dalam menjaga kebersihan, yaitu yang membuang sampah secara pribadi ke TPS dan yang mengupah orang lain untuk membersihkan. Terdapat dualisme perilaku dalam menyikapi kebersihan, bagi warga yang menetap merupakan keharusan dalam upaya menjaga kebersihan sedangkan bagi pendatang tidak ada sangsi moral yang memiliki kekuatan untuk mempengaruhi keikutsertaan dalam kegiatan gotong royong masyarakat

4. Pola yang terjadi dalam pengelolaan kebersihan lingkungan meliputi pra kondisi bahwa setiap kegiatan yang melibatkan orang banyak dilakukan musyawarah, dilakukan rutin menjelang perayaan peringatan hari ulang tahun Kemerdekaan, sentimentsentimen sosial muncul dalam kurun waktu menjelang acara puncak ditandai dengan kegiatan gotong royong

\section{Jurnal Sociopolitico}


Faktor-Faktor yang menghambat dan mendukung keteraturan sosial dalam kegiatan gotong royong mengelola lingkungan sebagai berikut :

1. Faktor penghambat adalah hubungan sekunder warga yang hanya memenuhi keinginan dari ketua warga sebagai tokoh masyarakat yang menggambarkan kehadiran semu warga dan toleransi yang rendah karena individualisme tinggi warga serta kurangnya kesadaran koletif warga akibat perubahan sosial masyarakat kota.

2. Faktor pendorong berupa kerjasama terlihat pada masyarakat yang tinggal secara permanen dan peran tokoh Ketua RT dalam menyeimbangkan, mempersatukan, kepentingan warga masyarakat.

\section{Referensi}

Ali, Mashud, (2004). Asset Liability Management: Menyiasati Resiko Pasar dan Risiko Opersional, Jakarta: PT. Gramedia.

Adi, Rukminto Isbandi, (2007), Intervensi Komunitas

Pengembangan

Masyarakat Sebagai Upaya

Pemberdayaan Masyarakat, Jakarta:

Raja Grafindo Persada.

Adi, Isbandi Rukminto. 2013. Pemberdayaan Pengembangan

Masyarakat, Dan Intervensi

Komunitas. Jakarta: Lembaga

Penerbit Fakultas Ekonomi

Universitas Indonesia

Adiyoso, Wignyo. (2009). Menggugat Perencanaan Partisipatif dalam Pemberdayaan Masyarakat.

Surabaya: ITS Press

Afifuddin. (2012). Pengantar Administrasi Pembangunan Konsep, Teori dan
Implementasinya di Era Reformasi. Bandung: Alfabeta

Al Hakim, Suparlan. (2015). Pengantar Studi Masyarakat Indonesia. Malang: Madani.

Arikunto, Suharsini. (2002). Prosedur Penelitan: Suatu Pendekatan Praktek. Jakarta: Rineka Cipta.

Arikunto, Suharsimi. (2010). Prosedur Penelitian "Suatu Pendekatan Praktik”, Jakarta: Rineka Cipta.

Badan Pusat Statistik Kabupaten Sukamara (2018). Kabupaten Sukamara Dalam Angka Tahun 2018. Sukamara: BPS Kabupaten Sukamara.

Dunn, William N, (2003), Analisa Kebijaksanaan Publik, Penterjemah, Muhadjir Darwin, Malang : Hanindita Offset (YA3).

Faisal, Sanapiah. (2007). Format-format Penelitian Sosial. Jakarta: PT.Rajagrafindo Persada

Kartasasmita, Ginanjar. (1994). Manajemen Pembangunan Untuk Negara Berkembang. Jakarta : PT Gelora Aksara Pratama.

Hafifah SJ Sumarto, (2003), Inovasi, Partisipasi Dan Good Governance, Jakarta: Yayasan Obor Indonesia. Hetifah SJ Sumarto, 2003, Inovasi, Partisipasi Dan Good Governance, Jakarta: Yayasan Obor.

Handayani,W. (2006). Psikologi keluarga. Jakarta : Pustaka Utama

Ife, Jim dan Tesoreiro, Frank. (2008). Community Development: Alternative Pengembangan Masyarakat di Era Globalisasi. Yogyakarta: Pustaka Pelajar.

Joko Widodo, (2001), Good Governance (Telaah dan Dimensi Akuntabilitas dan Kontrol Birokrasi Pada Era Desentralisasi dan Otonomi Daerah), Surabaya: Insan Cendekia. 
Koentjaraningrat. (1990). Kebudayaan Mentalitet dan Pembangunan. PT. Gramedia, Jakarta

Khairuddin. (2000). Pembangunan Masyarakat Tinjauan Aspek Sosiologi, Ekonomi dan Perencanaan. Yogyakarta: Liberty

MM Billah, (1996), Membalik Kuasa Negara Ke Kendali Rakyat, Jakarta : Pusat Studi Pengembangan Kawasan.

Mashoed. (2004). Pemberdayaan Masyarakat Miskin. Surabaya: Papyrus

Mardikanto, Totok, dan Soebiato, Poerwoko.(2017) Pemberdayaan Masyarakat dalam Perspektif Kebijakan Publik. Bandung : Alfabeta.

Miftah Thoha, (1992), Beberapa Aspek Kebijakan Birokrasi, Yogyakarta:

Miles, Matthew, dan Michael A. Huberman, (2009), Analisis Data Kualitatif : Buku Sumber tentang Metode-metode Baru, Penerjemah, Tjetjep Rohendi Rohidi dan Pendamping Mulyarto, Jakarta: Universitas Indonesia-Press.

Moleong, Lexy J. (2012), Metodologi Penelitian Kualitatif, Bandung: Remaja Rosdakarya.

Ndaraha, Taliziduhu. 1983. Partisipasi Masyarakat Desa Dalam Pembangunan Di Beberapa Desa. Jakarta: Yayasan Karya Dharma, IIP Siswanto, Budi. (2012), Pemberdayaan Masyarakat, Malang : Servaminora.

Soetrisno, Loekman. (1995). Menuju Partisipasi Masyarakat. Yogyakarta: Kanisius.

Sastropoetro, RA. Santoso, (1988), Partisipasi, komunikasi, Persuasi, dan Disiplin dalam Pembangunan, Bandung : Penerbit Alumni..
Sumarto dan Hetifa Sj. (2003) "Inovasi, Partisipasi dan Good governance". Bandung: Yayasan Obor Indonesia.

Suparman dan Soerjono, S. (1980) Beberapa Teori Sosiologi Tentang Struktur Masyarakat, Jakarta: Rajawali.

Sadu Wasistiono, (2003), Kapita Selekta Penyelenggaraan Pemerintahan, Bandung: Fokusmedia.

Saragi, Tumpal P. (2004), Mewujudkan Otonomi Masyarakat Desa "Alternative Pemberdayaan Desa".CV. Cipruy

Soerjono Soekanto dan Sri Mamuji, (2004), Penelitian Hukum Normatif "Suatu Tinjauan Singkat", Jakarta: PT Raja Grafindo Persada.

Siswanto, Budi (2012). Pemberdayaan Masyarakat.Malang: Servaminora

Sofian Efendi. (2005), Membangun Budaya Birokrasi untuk Good Governance. Lokakarya Reformasi Birokrasi. Jakarta: Departemen Pemberdayaan Aparatur Negara.

Sedarmayanti, (2007), Good Governance dan Good Corporate Governance, Bandung: Mandar Maju.

\section{Jurnal Sociopolitico}

